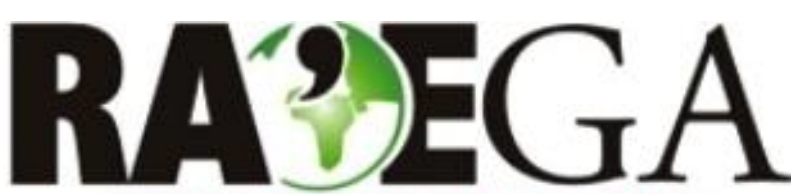

O ESPAÇO GEOGRÁFICO EM ANÁLISE

\title{
DINÂMICA ESPAÇO TEMPO DA DEMANDA POR INTERNET: AS CIDADES DO FUTURO NO CENÁRIO BRASILEIRO DE TELECOMUNICAÇÕES
}

\section{SPACE-TIME INTERNET DEMAND DYNAMIC: FUTURE CITIES IN THE BRAZILIAN TELECOMMUNICATION SCENARIO}

\author{
Matheus Pereira Libório ${ }^{1}$, Sandro Laudares ${ }^{2}$, Iara Sibele Silva ${ }^{3}$, Rafaela da Cunha Costa ${ }^{4}$, Patrícia \\ Bernardes $^{5}$, Philipe Sena Saviott ${ }^{6}$,
}

\section{RESUMO}

As necessidades da sociedade digital, como conectividade e acessibilidade, são alteradas de acordo com o tempo e o espaço. Logo, a dinâmica espaço-temporal da demanda por internet transforma o planejamento de investimentos em infraestrutura de telecomunicações em grande desafio. Antever as necessidades de uma sociedade digital em um futuro próximo é uma tarefa complexa, pois o desempenho do mercado é repleto de inovações e incertezas. Então, como convergir a oferta e a demanda das necessidades da sociedade digital com as cidades do futuro? Este trabalho apresenta pesquisa experimental em que uma metodologia é desenvolvida. Para isso, busca compreender os fenômenos que constituem o comportamento da demanda por internet e avaliar os efeitos espaço-temporais em sua dinâmica. Os resultados mostram que os efeitos ao longo do tempo têm impactos distintos sobre a demanda por internet em cada localidade. Tais observações mostram, sobretudo, que a demanda por internet é uma função dependente do espaço-tempo, capaz de influenciar decisões de investimento em infraestrutura de telecomunicações, maximizando o lucro e gerando externalidades positivas, como, por exemplo, na universalização do acesso à internet, a difusão da sociedade digital e a edificação das cidades do futuro.

Palavras-chave: sociedade digital; conectividade; mercado de incertezas; ambiente de inovações.

\section{ABSTRACT}

The needs of the digital society, such as connectivity and accessibility, are altered according to the time and space. These space-time demand dynamics turn the telecommunications infrastructure investment planning into a major challenge. Thus, predicting the needs of a digital society in the near future is a complex task, as the market performance is fraught innovations with uncertainties. So, how does one converge the supply and demand needs, cited in an environment that is constantly innovating, such as the future cities? Understanding the supply and demand of internet market behavior should include both expectations and the development of a long-term solution. This paper presents an experimental research where a methodology is developed. For this, it seeks to understand the phenomena that constitutes to the internet demand behavior and to evaluate the space-time effects on its dynamics. The proposed method indicates that temporal effects in the internet impacts demand differently as the analyzed city is changed. The results show that space-time may have an influence on telecommunications infrastructure investment decisions. Thus, the investment decision-making process would maximize profit when space-time analyses are considered. The contribution to telecommunications investment planning methods, will involve the digital society universalization in future cities.

Key-words: digital society; connectivity; uncertainty market behavior; innovative environment.

Recebido em: 01/04/2016

Aceito em: 26/02/2018

\footnotetext{
${ }^{1}$ Pontifícia Universidade Católica de Minas Gerais, Belo Horizonte/MG, e-mail: m4th32s@gmail.com

2 Pontifícia Universidade Católica de Minas Gerais, Belo Horizonte/MG, e-mail: sandrolaudares@gmail.com

${ }^{3}$ Pontifícia Universidade Católica de Minas Gerais, Belo Horizonte/MG, e-mail: iarasibelesilva@gmail.com

${ }^{4}$ Pontifícia Universidade Católica de Minas Gerais, Belo Horizonte/MG, e-mail: rcc.br@hotmail.com

${ }^{5}$ Pontifícia Universidade Católica de Minas Gerais, Belo Horizonte/MG, e-mail: patriciabernardes@pucminas.br

${ }^{6}$ Pontifícia Universidade Católica de Minas Gerais, Belo Horizonte/MG, e-mail: psaviott@hotmail.com
} 


\section{DINÂMICA ESPAÇO TEMPO DA DEMANDA POR INTERNET: AS CIDADES DO FUTURO NO CENÁRIO BRASILEIRO DE TELECOMUNICAÇÕES}

\section{INTRODUCTION}

The evolution of the digital society, reflecting the process of technological innovation, changes the way that people interact with technology. Every day more people and machines are connecting over the Internet, designing a digital habitat called Future City as shown in the works of Hall (1988), Batty et al. (2012) and Schaffers et al. (2011).

In the Future City, telecommunication networks connect everything to everybody. Personal computers, databases, mobile applications, sensors and device connections, demands billions of data streams in real time, at high speed and in an integrated way (NESSE; SVAET; STRASUNSKAS; GAIVORONSKI, 2013).

In Brazil, the telecommunications infrastructure has bottlenecks affecting the availability and quality of services, as reported in The Economist (2012). Understanding the historical process of telecommunications (RAUEN; HIRATUKA, FRACALANZA, 2011), particularly the conclusion of permanent precariousness of the sector since the 1960s (MATTOS; COUTINHO, 2005), implies on recognize the necessity to update and upgrade the telecommunications infrastructure. Because, according to Perera, Zaslavsky, Christen and Georgakopoulos, (2014), this update and upgrade are mandatory to support the demand for internet that the Future City context requires.

The first step to adapt the telecommunications infrastructure to a Future City context is to predict the demand for internet, exampled in Mack and Maciejewski (2015), Kaminska-Chuchmała (2014) and Kenny and Broughton (2013) works. However, these models have some conceptual problems. It occurs by the dissociation between the historical data and the uncertainty factors existing in the technological and innovative environment of a Future City. The absence of these factors modify the result of the prediction by leaving the influence of the space-time dynamics effect out of the demand behavior by mistake (EILEEN; MORAN, 2004).
This four-section research shows how the space-time dynamic contributed to the design of a Future City in the long-term (LOSKOT; HASSANIEN; FARJADY; RUFFINI; PAYNE, 2015). For this, a prediction method, detailed by Ellison and Nishio (2007), was used that considers a complex scenario filled with structural challenges in telecommunications infrastructure and unknown technologicalinnovative market.

\subsection{CONCEIVING A FUTURE CITY IN A BRAZILIAN SCENARIO TELECOMMUNICATION}

Overcoming structural barriers in the Brazilian telecommunication scenario, exposed by Neves and Bagarolli (2013), Conti et al. (2011) and Mocelin and Barcelos (2012), along with the challenges of the technological scenario, presented by $\mathrm{Yu}$, Cecati, Dillon and Simões (2011) and Gubbi, Buyya, Marusic and Palaniswami (2013), requires the knowledge of a complex, sophisticated and unknown environment. The environment of the Future City is formed by the coexistence of phenomena that suffer, without exception, from constant changes in space and time (HARVEY, 1989). With this, the conditions of capitalist production are modified, giving direction and rhythm to new activities related to technologies. In short, changes in space-time have the power to redefine social and economic relations (CARLOS, 2015). Transforming the Future City planning and design not only a challenge but also a necessity, requiring predictive models with space-time representation capable of capturing and establishing connections between phenomena of economic and geographical nature (CÂMARA; MONTEIRO; MEDEIROS, 2003).

Nevertheless, these computational representations must be used in context, not necessarily cartographic, but with an emphasis on the relations between the different social actors acting in the space (CÂMARA; MONTEIRO; MEDEIROS, 2003). For example, the historical, regulatory and economic 


\section{DINÂMICA ESPAÇO TEMPO DA DEMANDA POR INTERNET: AS CIDADES DO FUTURO NO CENÁRIO BRASILEIRO DE TELECOMUNICAÇÕES}

relationship between telecommunications companies and the Brazilian state.

In this case, the legacy of the relationship between the state and the stateowned telecommunications companies in Brazil was an inefficient, damaged, and unbalanced system caused by constant political and economic interventions to control inflation (ROTHBERG; KERBAUY, 2008).

This scenario was, according to Bolaño and Massae (2014) and Jurado Da Silva (2014) a picture of the scarcity of governmental financial resources, and the low capacity of reinvestment of state-owned enterprises. As a result, in the 1990s, the National Privatization Program began. Through Law No. 9,295, or the General Telecommunications Law, detailed by Pena, Abdalla Júnior and Pereira Filho (2013), allowed the participation of private companies in the operation of telecommunications services.

However, the reform of the telecommunications sector in the 1990s (MATTOS; COUTINHO, 2005) hasn't to date fostered the competitiveness that was expected, (MOCELIN; BARCELOS, 2012) and ended up depriving remote areas and regions with low economic interest of the telecommunications infrastructure (RAUEN et al., 2011).

By denying the telecommunications infrastructure, as mentioned, the relationship between people and technologies broke up (MACK; MACIEJEWSKI, 2015). This fact contributes to the unchanged economic constraints hindering the expansion of infrastructure, and to universalize the Future City (MOCELIN; BARCELOS, 2012).

In this sense, the conditions that configure the telecommunication dynamics in the Brazilian territory have been practically unchanged, imposing in the geographical space the problem of technological and social inequalities, consolidating the digital exclusion (GOMES, 2002). Therefore, besides the economic aspects, it is necessary to consider the geographical conditions in the discussion of telecommunications (JURADO DA SILVA, 2014). In this way it promotes technological inclusion, sustainability and social development (ALBUQUERQUE, 2007).

This scenario can be confirmed by recent data on broadband access in Brazil. According to Anatel (2018), only ten cities account for $34 \%$ of the total access. This inequality is evidenced when we associate population data with broadband access. In this case, in the 55 largest municipalities, we find $32 \%$ of the country's population and $59 \%$ of the total broadband access. (IBGE, 2018; ANATEL 2018)

Therefore, implementation of innovations in new architectures of networks has a catalyst role in fair dissemination of digital society. These innovations have the potential to increase the capacity, availability of the network, and reducing deployment and operating costs. It also allows the enabling of new services, strengthened tolerance against cyber-attacks, improved reset failing, extending the data streams traffic and the generation of more integrated services (PAUL; PAN; JAIN, 2011).

\subsection{FUTURE CITY TECHNOLOGIES}

The first concepts of the Future City (ROUSE, 1967) have been evolving, to conceive a hyperactive connected people ecosystem (ANDONE; HOLOTESCU; GROSSECK, 2014), which takes part by collaborating actively in the activities and decisions of the city. The citizen interacts geographically in the urban space (ATZMANSTORFER; RESL; EITZINGER; IZURIETA, 2014), becoming an active subject in the city planning and resource management, by entering information, anytime, anywhere.

The achievement of this phenomenon is new in the industry (PERERA et al., 2014). This changes the way, speed and intensity of how people relate to cities. In other words, the distance between city and the citizen is reduced. The evolved changes in the city are more assertive as its alignment changes to the citizen's needs. This alignment is a network of 


\section{DINÂMICA ESPAÇO TEMPO DA DEMANDA POR INTERNET: AS CIDADES DO FUTURO NO CENÁRIO BRASILEIRO DE TELECOMUNICAÇÕES}

lines that connects everything in the city to

everyone, as in figure 1.

Figura 1 - Future City: people-city connectivity environment

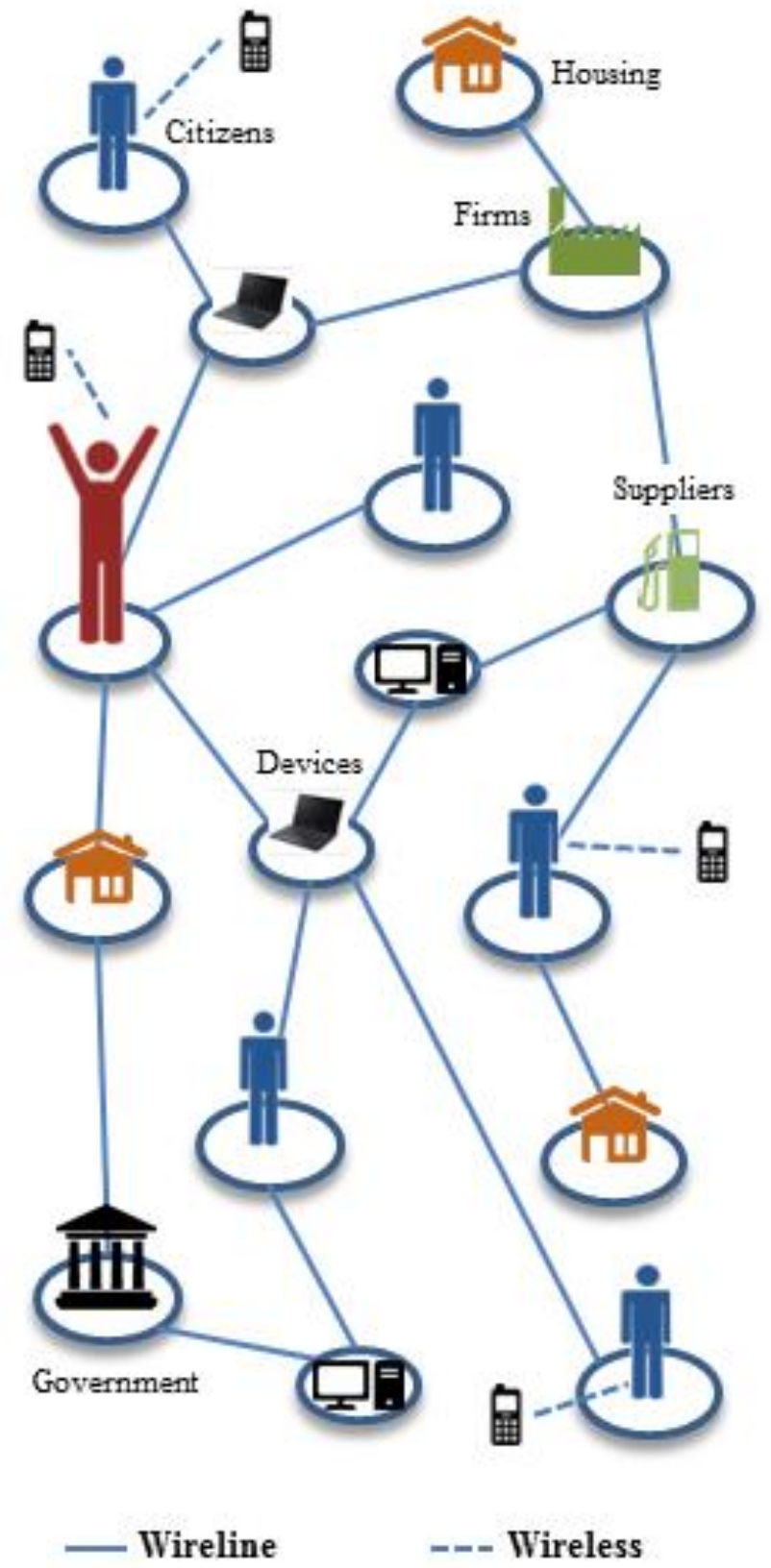

In a world of exponential changes, the design of the Future City becomes a goal which must consider the higher populations and economic growth (SAATY; SAGIR, 2012), the environmental threats (MORIARTY; HONNERY, 2015), and the telecommunications network security (GESSNER; OLIVEREAU; SEGURA; SERBANATI, 2012).

\subsection{PLANNING UNDER UNCERTAINTIES}

The demand for internet is an effect of the process of technological innovation (LIMA; MORO; JAYME JUNIOR, 2006), where the internet supply promote the increase of technology use and a higher demand. This logic leads to the discovery of new applications and through this more and more internet demand. 


\section{DINÂMICA ESPAÇO TEMPO DA DEMANDA POR INTERNET: AS CIDADES DO FUTURO NO CENÁRIO BRASILEIRO DE TELECOMUNICAÇÕES}

\begin{abstract}
Marketing and technological
\end{abstract} uncertainties avoid the user, because they know what their demand for internet will be in two, five and ten years, so the telecommunications infrastructure planning becomes a difficult and important task. Soon, as the cost of the infrastructure is high, even if consumers are willing to pay for services, the providers will not want to invest without the guarantee of a return on their investment (LIMA et al., 2006).

Experiments dedicated to forecast internet demand for planning actions (GONZÁLEZ-APARICIO et al., 2014; LI; LAM; QIANG; ZOU; CAI, 2015; LUKAS, 2015; SITUMORANG; ADHY, 2014) in addition to those associated with space-time Geostatistical estimation methods (KAMINSKACHUCHMAŁA, 2014), always demonstrate the difficulty on models of construction, as already observed by Loskot et al. (2015).

The internet demand prediction made through temporal patterns, incorporates in its time series records of innovation and technology processes. This paper incorporates the concept that the historical data of those processes guides the internet demand estimation model (LIMA et al., 2006).

Thus, the current prediction model, tools and techniques were used in this research to analyze the internet demand for a Future City in the Brazilian scenario, observing its space-time dynamic. The space-time approach enriches the discussion about the universal internet access as other analysis that also seeks to stimulate policies for telecommunications expansion and improvement (MACK; MACIEJEWSKI, 2015).

\subsection{SPACE TIME INTERNET DEMAND DYNAMIC}

The evolution of the technological structure of The Future City advances every interaction of citizens in the decision making process. These successful interactions, enabled by spatial platforms, occur in a location based way. Thus, it takes place in a desired geographical location. It modifies the social and economic dynamics in the urban space (ATZMANSTORFER et al., 2014).

These modifications involve spacetime concepts which allows for the understanding of how reproduction and representation forms of social and economic phenomena contribute towards predicting events such as the internet demand (HARVEY, 1989). According to Santos (1996), it is indispensable to technically study and think of events related to space from a temporal perspective, because the possibility of man achieving them both now and in the future is different.

The Future City, composed by an aggregate of technological phenomena which varies complexity and unpredictability over time, redefine urban spaces continuously (CÂMARA; MONTEIRO; MEDEIROS, 2003). Therefore, the social and economic injustices that limit the equitable digital society have redefined progress all the time, changing the population space dynamics, thus increasing their capacity to overcome economic limitations. Chaining events related to population characteristics and growth in space and the technological evolution in time, may ensure that the free access to applications and innovative technologies becomes a universal reality in the Future City (ALENCAR; BARROSO; ABREU, 2014).

\section{MATERIALS AND METHODS}

This paper presents an experimental research, where a methodology is developed to evaluate the effects of space-time dynamics on internet demand. The following software tools used were: Forecast-pro and Microsoft Excel. The research is detailed in the following steps: data collection, internet demand prediction and mapping space-time dynamics, shown in Fig. 2. 


\section{DINÂMICA ESPAÇO TEMPO DA DEMANDA POR INTERNET: AS CIDADES DO FUTURO NO CENÁRIO BRASILEIRO DE TELECOMUNICAÇÕES}

Figura 2 - Stage sequence for space-time on internet demand mapping

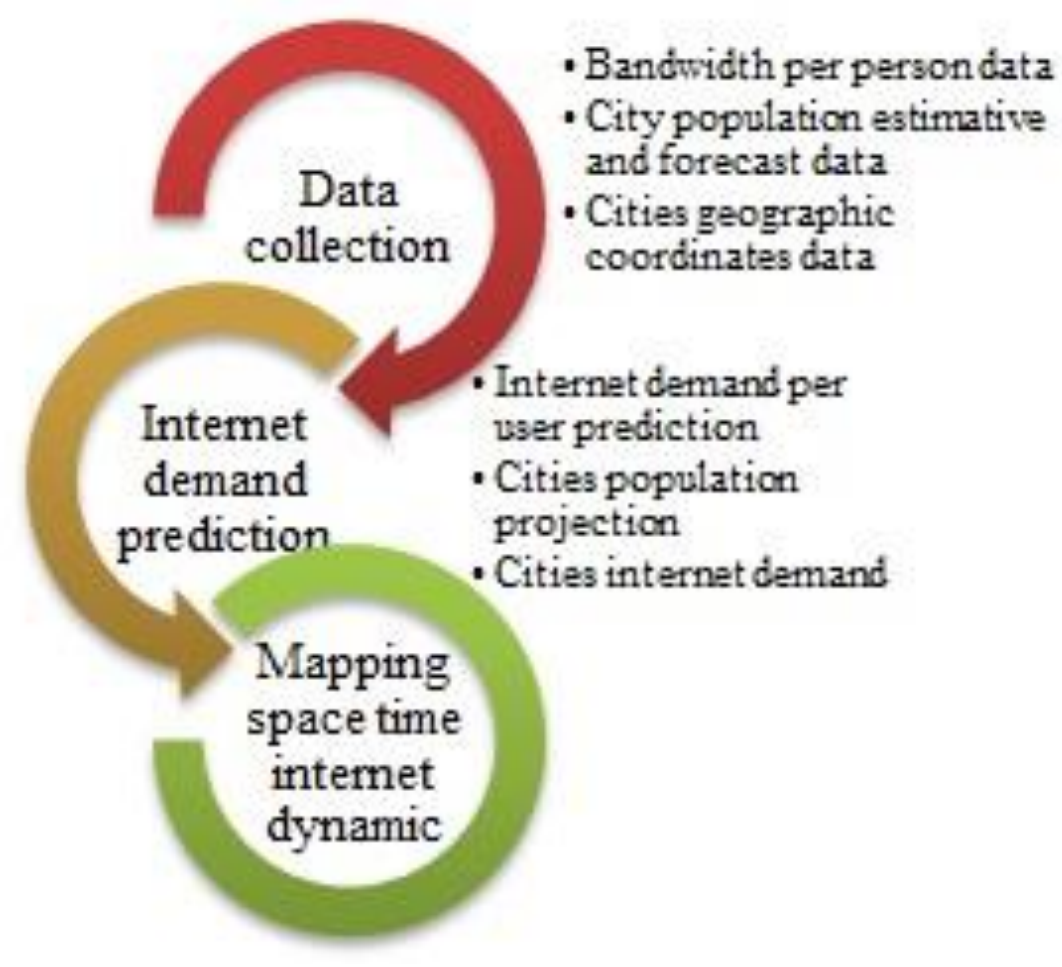

\subsection{DATA COLLECTION}

The data collection for internet prediction model, the chosen cities, their respective population projection and the spacetime representation, are summarized in Table 1.

INDICATOR

\begin{tabular}{|c|c|}
\hline $\begin{array}{l}\text { INTERNATIONAL TELECOMMUNICATION UNION } \\
\text { (ITU, 2018) }\end{array}$ & Internet bandwidth per user - bits per second \\
\hline $\begin{array}{l}\text { GEOGRAPHY STATISTIC BRAZILIAN INSTITUTE } \\
\text { (IBGE, 2018) }\end{array}$ & $\begin{array}{l}\text { Municipality Population Estimates }(P x) \text {; Brazil } \\
\text { Population Projections } 2013-2030(T x)\end{array}$ \\
\hline
\end{tabular}

\subsection{INTERNET DEMAND PREDICTION}

This stage comprises four steps to estimate the Future City internet demand: internet demand per person prediction model (exponential smoothing method), city selection process for experiments (random method), city population projection (method by Geographic and Statistical Brazilian Institute - IBGE growth rates) and the internet demand function for the chosen cities.

The internet consumption database per user for Brazil is the basis for the internet demand prediction in a Future City. Called $D x$, estimated by the method of exponential smoothing. The exponential smoothing explored by Gijbels, Pope and Wand (1999) is an accurate, functional and widely used forecast model shown in Laviola (2003) and Gardner (1985). With a robust technique it works by identifying and extracting trend and seasonality, even for short-term and volatile data, projecting the future (STEELWAGEN; GOODRICH, 2008). Than it is possible to associate the forecasted data to spatial features (SUN; PAPADIAS; TAO; LIU, 2004).

The selection of five cities in Minas Gerais State is made randomly by Microsoft Excel. The selection process consists of 


\section{DINÂMICA ESPAÇO TEMPO DA DEMANDA POR INTERNET: AS CIDADES DO FUTURO NO CENÁRIO BRASILEIRO DE TELECOMUNICAÇÕES}

attributing a single random value to each city, identifying the five highest values, which each represents a city in Minas Gerais.

The population projection of the chosen cities was made based on the estimated population of the year 2015 Px multiplied by the population growth rates between years 2015 and 2018, represented by $T x$.

Thus, the internet demand function for a Future City may be defined by:

$$
D_{x} \times[P x *(1+T x)] \text {. }
$$

\subsection{MAPPING SPACE TIME INTERNET
INTE DYNAMICS}

Money is a component dependent on space-time. Thus, it is always possible to maximize profit considering how the use of technology changes in space-time models (BRANDÃO; ABREU, 2003)

Therefore, in this stage, the dynamic view time-line of internet demand by city is mapped. It is evidence of how monetary benefits are modified by internet demand changes over space and time.

\section{RESULTS AND DISCUSSIONS}

The research shows how the time (technological change) and space (size and growth of the city's population) dynamic affects demand for internet, and consequently in the design of the Future City infrastructure. This is based on internet demand advance in spacetime supporting the telecommunications infrastructure expansion.

The first step is looking at figure 3 , and seeing the results of the internet demand prediction per person in kbps in Brazil, until year 2018. The forethought made by the exponential smoothing method has the statistical explanation parameter measured by Adjusted $\mathrm{R}^{2}$ greater than 0.82 that according to Hair, Black, Babin, Anderson and Tatham (2009) is within the desirable range of legitimacy.

Figura 3 - Internet bandwidth per user. Source: IBGE (historical data) and authors (prediction)

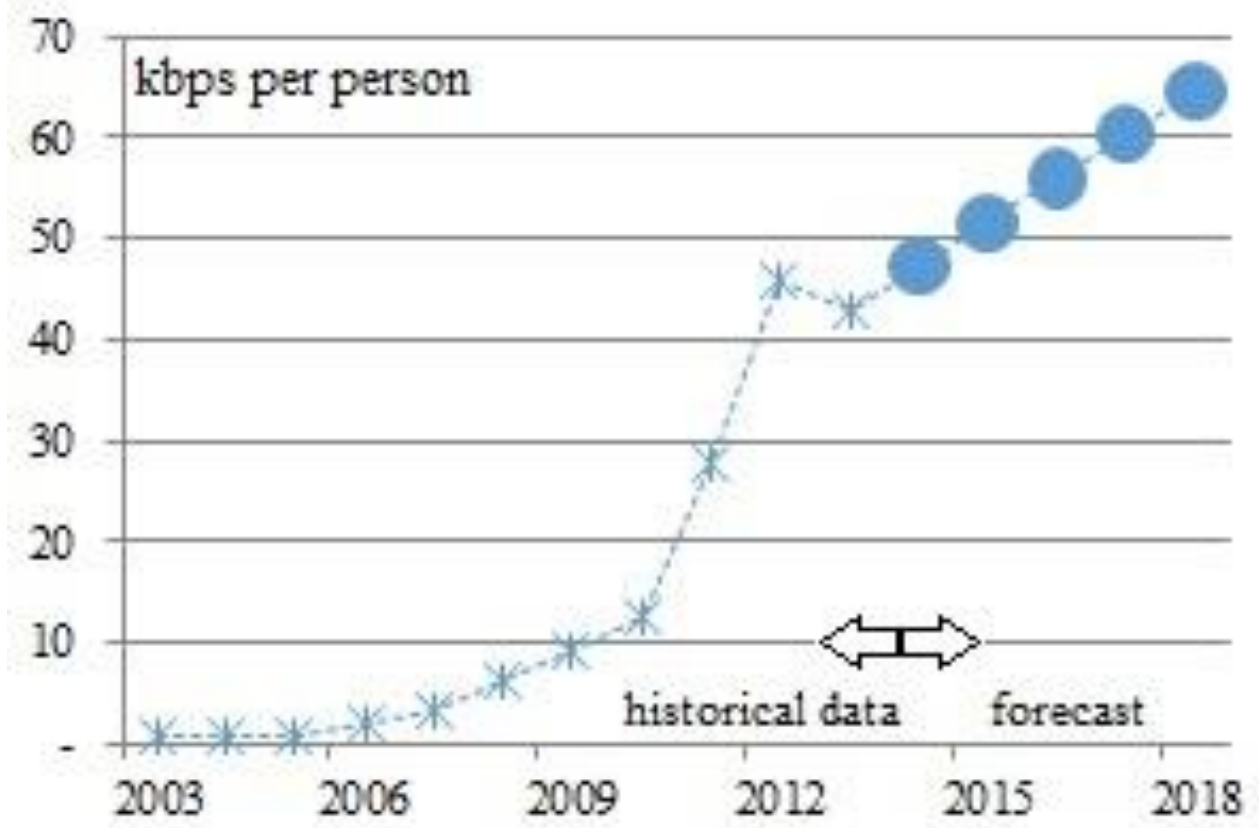

The validity of the results is ratified in figure 4 by comparing the exponential smoothing method against simple regression. The difference between the forecasting results may be seen by points. This difference represents a whole year of internet growth. Therefore, the internet demand calculated by the exponential smoothing method for 2018, will only be achieved if using the simple regression method in 2019. The statistical 


\section{DINÂMICA ESPAÇO TEMPO DA DEMANDA POR INTERNET: AS CIDADES DO FUTURO NO CENÁRIO BRASILEIRO DE TELECOMUNICAÇÕES}

parameter of simple regression $R^{2}$ was 0.77 ,

than the exponential smoothing method. representing a lesser degree of explanation

Figura 4 - Forecast Method Comparison. Source: authors

\section{kbps per person}

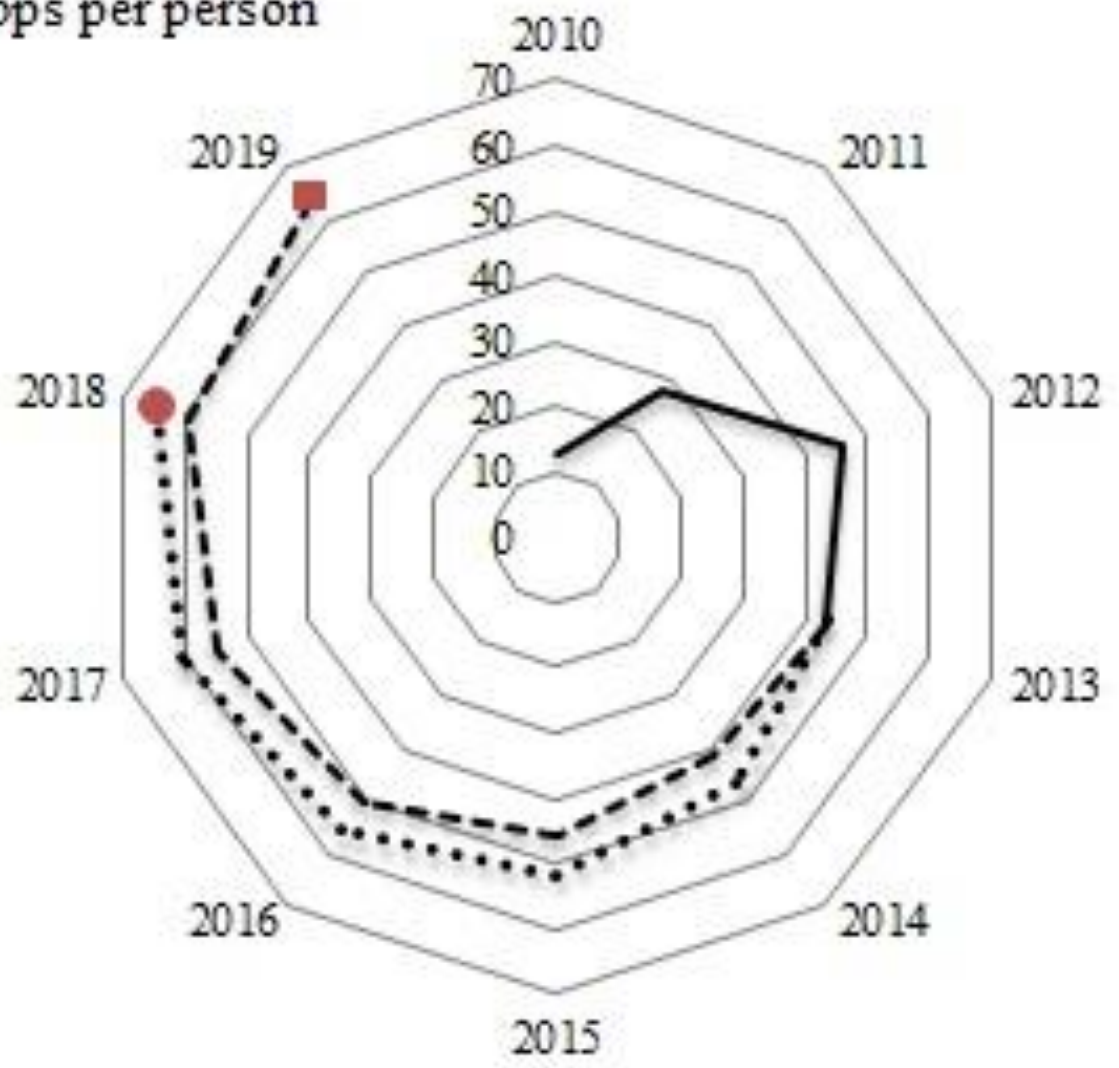

- Bivariate Regression

\section{Historical Data}

The analysis confirms the importance of the chosen method to achieve the universal Future City conception goal.

The second step applies the Excel random function to select cities for the
Exponential Smoothing

experiment, whose populations are projected in the third step. Table 2 summarizes the results of these two steps by using the population growth rate of $29,7 \%$, between years 2015 and 2018.

\begin{tabular}{|c|l|c|c|}
\hline Index & \multicolumn{1}{|c|}{ City Name } & $\begin{array}{c}\text { Estimation } \\
\mathbf{2 0 1 5}\end{array}$ & $\begin{array}{c}\text { Projection } \\
\mathbf{2 0 1 8}\end{array}$ \\
\hline A & Cristais & 628 & 815 \\
\hline B & Novo Oriente de Minas & 551 & 715 \\
\hline C & Lagoa Grande & 474 & 615 \\
\hline D & Estrela do Sul & 403 & 523 \\
\hline E & Santo Antônio do Retiro & 372 & 482 \\
\hline
\end{tabular}

Tabela 2 - Population Projection Results in Millions 2015-18. Source: authors

In the fourth step, multiplying the internet demand per person until 2018, by the city population, determines the Future City internet demand. These results, presented in 


\section{DINÂMICA ESPAÇO TEMPO DA DEMANDA POR INTERNET: AS CIDADES DO FUTURO NO CENÁRIO BRASILEIRO DE TELECOMUNICAÇÕES}

figure 5, summarize research stage three,

overcome, in each space. representing the year when constraints will be

Figura 5 - Space-time effect to overcome constraints

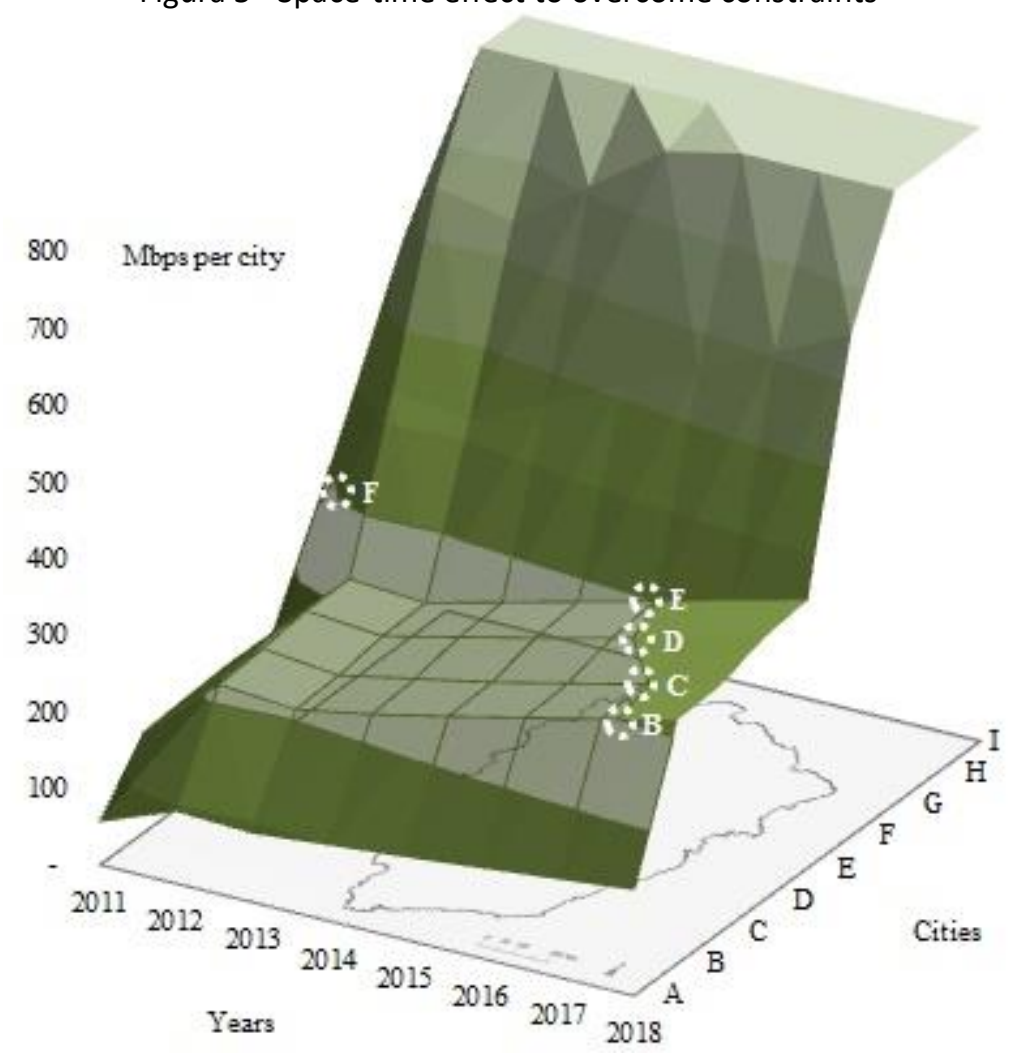

The map allows us to define the precise time (year) that the minimum internet demand necessary to attract investments for telecommunications infrastructure is achieved. At this time (year), the conceived Future City is financially possible, for instance, this simulation considers a $450 \mathrm{Mbps}$ internet demand as the break-even point.

Considering this break-even point, the city population and its respective internet demand, the Future City conception can be expressed by a space-time function. In this case, the Future City will be feasible when $x \geq a_{t} \times b_{t}$, where $x$ is the break-even-point, $a_{t}$ is the internet demand per user in time $t$ and $b_{t}$ is the city population in time $t$.

In this way, the temporal effects have different impacts on the conditions of space in each city analyzed. Therefore, overcoming the telecommunications infrastructure supply constraints that occur at different times (year) for each city.

The time (year) to conceive the Future City is associated with the chosen City. In this experiment city $A$ and $B$ are able to conceive the Future City in 2011, while the cities C, D and E are able to conceive their Future City in 2015, 2017 and $2018 \mathrm{C}$ respectively.

\section{CONCLUSION}

This paper applies the exponential smoothing technique to predict the demand for internet in a technological environment that has been called a Smart City. The experiment shows the influence of a space-time dynamic on internet demand. The results of the spacetime influence in the internet demand phenomenon have changed in the decisions 


\section{DINÂMICA ESPAÇO TEMPO DA DEMANDA POR INTERNET: AS CIDADES DO FUTURO NO CENÁRIO BRASILEIRO DE TELECOMUNICAÇÕES}

concerning the time (year) and city place to make telecommunications infrastructure investments, thereafter a Future City establishment.

The experiments based on research related to technological predictions and above all, the internet forecasts, upholds the principle, which by stimulating the supply of internet promotes the demand for this. Therefore, the telecommunications offer increase would create the condition for technological growth, multiplying the internet demand then becoming feasible to conceive the Future City.

The space-time approach exposes to observation, analysis and explanation, the internet demand dimension changes according to the place or period that is focused on. Because of that, this approach will insert order and accuracy into the rational decision-making process. The order is associated with investment prioritization and the accuracy is associated with effectiveness of investment execution. Both will give assertiveness to rational decisions for telecommunications infrastructure investments and support the Future City deployment.

As result of the developed knowledge in this paper, it would be feasible to overcome the Brazilian structural barriers and to promote the digital society universally. The regional context of the State of Minas Gerais is inserted in this technological and social process.

Therefore, government institutions, public companies and researches may assume their respective roles. PUC Minas, the State's largest private University, manages technological development through the dissemination of scientific knowledge. CEMIGTelecom, a state-owned telecommunication company provides telecommunications infrastructure. FIEMG, Federation of Industry of State of Minas Gerais stimulates competitiveness, innovation, sustainability and the generation of new business for industry. FAPEMIG, the Research Foundation of the State of Minas Gerais, inducts, promotes and foments research and innovation in science and technology. PRODEMGE, Information Technology Company, delivers solutions in Information and Communication Technology and the continued development of public administration and its agents.

The application of more complex prediction models such as dynamic regression, or to include the Smart Grids and Internet of Things technological scenario might improve the forecast accuracy and the technological basis. Even so, those contributions would not remove the relevance of space-time elements on Future City design.

\section{REFERENCES}

ALBUQUERQUE, H. H. F. Inclusão digital para a redução de desigualdades sociais: a apropriação e o uso das tecnologias da informação para a atuação cidadã. Pesquisa Brasileira em Ciência da Informação e Biblioteconomia 1, n. 2, 2007.

ALENCAR, B. J.; BARROSO, L. C.; ABREU, J. F. Análise de componentes principais aplicada ao tratamento de dados espaciais. In: $\mathrm{CISCl}$. DÉCIMA TERCERA CONFERENCIA IBEROAMERICANA EN SISTEMAS, CIBERNÉTICA E INFORMÁTICA. Orlando-Florida-EUA. [S.I.], 2014.

ANATEL, Agência Nacional das Telecomunicações. Acessos - Banda Larga Fixa. Acesso em 18 fev. 2018. Disponível em: http://www.anatel.gov.br/dados/2015-02-0418-32-09.

ANDONE, D.; HOLOTESCU, C.; GROSSECK, G. Learning communities in smart cities. case studies. In: IEEE. WEB AND OPEN ACCESS TO LEARNING (ICWOAL), 2014 International Conference on. [S.I.], 2014. p. 1-4.

ATZMANSTORFER, $K$. et al. The geocitizenapproach: community-based spatial planningan ecuadorian case study. Cartography and Geographic Information Science, Taylor \& Francis, v. 41, n. 3, p. 248-259, 2014.

BATTY, M., AXHAUSEN, K. W., GIANNOTTI, F., POZDNOUKHOV, A., BAZZANI, A., WACHOWICZ, M., PORTUGALI, Y. Smart cities of the future. 


\section{DINÂMICA ESPAÇO TEMPO DA DEMANDA POR INTERNET: AS CIDADES DO FUTURO NO CENÁRIO BRASILEIRO DE TELECOMUNICAÇÕES}

The European Physical Journal Special Topics, Springer, v. 214, n. 1, p. 481-518, 2012.

BOLAÑO, C.; MASSAE, F. A situação das telecomunicações no Brasil ao final do processo de privatização. Intercom-Revista Brasileira de Ciências da Comunicação, v. 23, n. 1, 2014.

BRANDÃO; ABREU, J. F. Deslocamento, tempo e dinheiro: uma análise exploratória de convergência espacial. Geografia, modelos de análise espacial e GIS. Editora PUCMINAS, 2003.

CÂMARA, G; MONTEIRO, A. M. V.; MEDEIROS, JS de. Representações computacionais do espaço: fundamentos epistemológicos da ciência da geoinformação. Geografia, Rio Claro, v. 28, n. 1, p. 83-96, 2003.

CARLOS, A. Fani A. A reprodução do espaço urbano como momento da acumulação capitalista. Crise Urbana, p. 25-35, 2015.

CONTI, M. et al. Research challenges towards the future internet. Computer Communications, Elsevier, v. 34, n. 18, p. 2115-2134, 2011.

EILEEN, M. M.; MORAN, J. Predicting bandwidth demand and network planning implications on the internet. University of Michigan: Merit Technical Report, 2004.

ELLISON, J.; NISHIO, Y. Prediction method and system. 2007.

GARDNER, E. S. Exponential smoothing: The state of the art. Journal of forecasting, Wiley Online Library, v. 4, n. 1, p. 1-28, 1985.

GESSNER, D. et al. Trustworthy infrastructure services for a secure and privacy respecting internet of things. In: IEEE. TRUST, SECURITY AND PRIVACY IN COMPUTING AND COMMUNICATIONS (TrustCom), 2012 IEEE 11th International Conference on. [S.I.], 2012. p. 998-1003.

GIJBELS, I.; POPE, A.; WAND, M. Understanding exponential smoothing via kernel regression. Journal of the Royal Statistical Society: Series B (Statistical Methodology), Wiley Online Library, v. 61, n. 1, p. 39-50, 1999.

GOMES, E. Exclusão digital: um problema tecnológico ou social. Trabalho e Sociedade. Ano, v. 2, 2002.
GONZÁLEZ-APARICIO, M. T. et al. Measuring temporal redundancy in sequences of video requests in a news-on-demand service. Telematics and Informatics, Elsevier, v. 31, n. 3, p. 444-458, 2014.

GUBBI, J. et al. Internet of things (iot): A vision, architectural elements, and future directions. Future Generation Computer Systems, NorthHolland, v. 29, n. 7, p. 1645-1660, 2013.

HAIR, J. F. et al. Análise multivariada de dados. [S.I.]: Bookman, 2009.

HALL, P. Cities of tomorrow. [S.I.]: Blackwell Publishers, 1988.

HARVEY, D. The condition of postmodernity. [S.I.]: Blackwell Oxford, 1989. v. 14.

IBGE. Estimativas de População. Acesso em 18 fev. 2018. Disponível em: $\mathrm{ftp} / / / \mathrm{ftp}$. ibge.gov.br/Estimativas_de_Populacao /Estimativas_2017/estimativa_dou_2017.pdf

ITU, I. Measuring the Information Society Report: ICT Country profiles. Geneva Switzerland: International Telecommunication Union, 2017. Acesso em 25 fev. 2018. Disponível em: https://www.itu.int/en/ITUD/Statistics/Documents/publications/misr2017 /MISR2017_Volume2.pdf.

JURADO DA SILVA, P. F. Evolução das telecomunicações e integração territorial do Brasil. Revista Novedades en Población, v. 10, n. 19, p. 104-112, 2014.

KENNY, R.; BROUGHTON, T. Domestic demand for bandwidth an approach to forecasting requirements for the period 2013-2023. no. November, 2013.

LAVIOLA, J. J. Double exponential smoothing: an alternative to kalman filter-based predictive tracking. In: ACM. Proceedings of The Workshop On Virtual Environments 2003. [S.I.], 2003. p. 199-206.

LI, K. et al. A cyberinfrastructure for community resilience assessment and visualization. Cartography and Geographic Information Science, Taylor \& Francis, v. 42, n. sup1, p. 3439, 2015.

LIMA, I. C.; MORO, S.; JUNIOR, F. G. J. Ciclos e previsão cíclica: um modelo de indicadores 


\section{DINÂMICA ESPAÇO TEMPO DA DEMANDA POR INTERNET: AS CIDADES DO FUTURO NO CENÁRIO BRASILEIRO DE TELECOMUNICAÇÕES}

antecedentes para a economia brasileira. In: ANPEC-ASSOCIAÇÃO NACIONAL DOS CENTROS DE PÓS GRADUAÇÃO EM ECONOMIA [Brazilian Association of Graduate Programs In Economics]. Anais do XXXIV Encontro Nacional de Economia Proceedings of the 34th Brazilian Economics Meeting. [S.I.], 2006.

LOSKOT, P., HASSANIEN, M. A., FARJADY, F., RUFFINI, M., \& PAYNE, D. Long-term drivers of broadband traffic in next-generation networks. Annals of telecommunications-annales des télécommunications, Springer Paris, v. 70, n. 12, p. 1-10, 2015.

LUKAS, L. Advanced GIS functions for tactical radio communication planning. In: IEEE. MILITARY TECHNOLOGIES (ICMT), 2015 International Conference on. [S.I.], 2015. p. 15.

MACK, E. A.; MACIEJEWSKI, R. A profile of visual analytical toolkits for understanding the spatiotemporal evolution of broadband provision. Telecommunications Policy, Elsevier, v. 39, n. 3, p. 320-332, 2015.

MATTOS, C.; COUTINHO, P. The Brazilian model of telecommunications reform. Telecommunications Policy, Elsevier, v. 29, n. 5, p. 449-466, 2005.

MOCELIN, D. G.; BARCELOS, R. L. G. Tecnologia, competitividade e regulação: a estruturação do mercado das telecomunicações no brasil. Caderno CRH, SciELO Brasil, v. 25, n. 66, p. 409432, 2012.

MORIARTY, P.; HONNERY, D. Future cities in a warming world. Futures, Elsevier, v. 66, p. 4553, 2015.

NESSE, P. J. et al. Assessment and optimization of business opportunities for telecom operators in the cloud value network. Transactions on Emerging Telecommunications Technologies, Wiley Online Library, v. 24, n. 5, p. 503-516, 2013.

NEVES, L. C.; BAGAROLLI, A. Os desafios da implementação dos projetos-piloto de smart grid no brasil. Cad. CPqD Tecnologia, Campinas, v. 9, n. 1, p. 15-22, 2013.

PAUL, S.; PAN, J.; JAIN, R. Architectures for the future networks and the next generation internet: A survey. Computer Communications, Elsevier, v. 34, n. 1, p. 2-42, 2011.
PENA, A. G.; ABDALLA JÚNIOR, H.; PEREIRA FILHO, J. L. A banda larga e o cenário brasileiro das telecomunicações. Revista de Direito, Estado e Telecomunicações, v. 4, n. 1, p. 23730, 2012.

PERERA, C. et al. Sensing as a service model for smart cities supported by internet of things. Transactions on Emerging Telecommunications Technologies, Wiley Online Library, v. 25, n. 1, p. 81-93, 2014.

RAUEN, C. V.; HIRATUKA, C.; FRACALANZA, P. S. Universalization of telecommunications services: Public policies in the OECD and in Brazil. International Journal of Development Issues, Emerald Group Publishing Limited, v. 10, n. 2, p. 108-122, 2011.

ROTHBERG, D.; KERBAUY, M. T. M. Lei de telecomunicações e orgão regulador no brasil: desafios e obstáculos à luz da experência britânica e européia. Estudos de Sociologia, v. 13, n. 24, 2008.

ROUSE, J. W. Cities that Work for Man, Victory Ahead. [S.I.]: publisher not identified, 1967.

SAATY, T. L.; SAGIR, M. Global awareness, future city design and decision making. Journal of Systems Science and Systems Engineering, Springer, v. 21, n. 3, p. 337-355, 2012.

SANTOS, Milton. Espaço, mundo globalizado, pos-modernidade. Margen, v. 2, p. 9-22, 1996.

SCHAFFERS, H., KOMNINOS, N., PALLOT, M., TROUSSE, B., NILSSON, M., \& OLIVEIRA, A. Smart cities and the future internet: Towards cooperation frameworks for open innovation. Future Internet Assembly, Springer, v. 6656, p. 431-446, 2011.

SITUMORANG, H.; ADHY, L. On the development of thematic gis database application platform for reforming space and area of government city/district. In: IEEE. TELECOMMUNICATION SYSTEMS SERVICES AND APPLICATIONS (TSSA), 2014 8th International Conference on. [S.I.], 2014. p. 15.

STEELWAGEN, E.; GOODRICH, R. Forecast prostatistical reference manual. Belmont, MA, 2008. 
DINÂMICA ESPAÇO TEMPO DA DEMANDA POR INTERNET: AS CIDADES DO FUTURO NO CENÁRIO BRASILEIRO DE TELECOMUNICAÇÕES

SUN, J. et al. Querying about the past, the present, and the future in spatio-temporal databases. In: IEEE. DATA ENGINEERING, 2004. Proceedings. 20th International Conference on. [S.I.], 2004. p. 202-213.

THE ECONOMIST. The next big blackout? Economist (United Kingdom), v. 404, n. 8797, 2012. Disponível em: <http://www.scopus.com>.

YU, X. et al. The new frontier of smart grids. Industrial Electronics Magazine, IEEE, IEEE, v. 5, n. 3, p. 49-63, 2011. 